\title{
ANALISIS PENILAIAN TINGKAT KESEHATAN BANK DENGAN METODE RISK PROFILE, GOOD CORPORATE GOVERNANCE, EARNINGS, CAPITAL
}

\author{
Santi Octaviani \\ antieoct@gmail.com \\ Nadya Saraswati \\ Universitas Serang Raya
}

\begin{abstract}
ABSTRAK
Penelitian ini bertujuan untuk mengetahui tingkat kesehatan bank umum BUMN tahun 2012-2016 ditinjau dari aspek Risk Profile, Good Corporate Governance, Earnings, Capital secara keseluruhan. Metode penelitian ini adalah menggunakan deskriptif dengan pendekatan kuantitatif. Populasi penelitian ini seluruh bank BUMN yang terdaftar di Bursa Efek Indonesia tahun 2012-2016. Teknik pengumpulan data yang dipergunakan adalah teknik dokumentasi dan teknik kepustakaan. Teknik analisis data yang digunakan adalah analisis kesehatan bank dengan pendekatan Risiko (Risk-Based Bank Rating) dengan cakupan penilaian meliputi faktor-faktor RGEC.

Hasil dari penelitian ini menunjukan secara keseluruhan tingkat kesehatan bank BUMN selama periode 2012-2016, dari segi Profil Risiko yaitu dengan menganalisis risiko kredit yang diwakili dengan rasio Non Perfoming Loan (NPL) dikatakan "Sehat" dan dari analisis Risiko Kredit yang diwakili dengan rasio Loan to Deposite Ratio (LDR) dapat dikatakan "Cukup Sehat". Sedangkan dari segi Good Corporate Governance (GCG) tingkat kesehatan bank BUMN dikatagorikan "Sehat". Secara keseluruhan tingkat kesehatan bank dari segi Earnings (Rentabilitas) yaitu dengan menganalisis rasio Return On Asset (ROA) atau perolehan laba berdasarkan aset dan rasio Net Interest Margin (NIM) atau kemampuan manajemen dalam mengendalikan biaya-biaya bank dikatakan "Sangat Sehat". Dan dari segi permodalan yang diwakili dengan menghitung rasio Capital Adequacy Ratio (CAR) bank dikatakan "Sangat Sehat". Hasil analisis tingkat kesehatan bank umum BUMN berdasarkan metode RGEC selama tahun 2012-2016 menunjukkan bahwa kesehatan bank berada pada Peringkat Komposit 1(PK 1) yaitu terlihat dari keempat aspek yang diukur berupa Risk Profile, GCG, Earnings, dan Capital , secara keseluruhan berada dalam peringkat "Sangat Sehat".
\end{abstract}

Kata Kunci : Risk Profile, Good Corporate Governance, Earnings, Capital

\section{PENDAHULUAN}

Menurut undang-undang no.7 tahun 1992 tentang perbankan yang telah diubah dengan Undang-undang No. 10 tahun 1998 yang dimaksudkan dengan bank adalah "Badan usaha yang menghimpun dana dari masyarakat dalam bentuk simpanan, dan menyalurkan kepada masyarakat dalam bentuk kredit dan atau bentuk-bentuk lainnya dalam rangka meningkatkan taraf hidup masyarakat banyak" (Malayu S.P Hasibuan, 2011:1). Menjadi lembaga keuangan berkompeten bank harus mampu melakukan fungsinya sesuai dengan aturan yang ada. Kompetensi ini sangat berguna untuk meningkatkan tingkat kepercayaan masyarakat terhadap sektor perbankan itu sendiri. Guna membangun hubungan yang baik dengan masyarakat, bank harus memiliki tingkat kesehatan bank yang baik. Penilaian ini dapat dijadikan salah satu pemicu meningkatnya tingkat kepercayaan masyarakat kepada bank. Dari banyaknya jenis bank umum yang ada di Indonesia, Bank umum BUMN lebih banyak diminati oleh masyarakat sebagai tempat untuk menyimpan atau menginvestasikan dana yang mereka miliki 
karena dianggap lebih aman dan terpercaya karena dimiliki oleh negara. Menurut Kasmir (2012: 29) Bank Milik Pemerintah adalah bank yang akte pendirian maupun modal dimiliki oleh Pemerintah, sehingga seluruh keuntungan bank dimiliki oleh pemerintah pula. Bank yang termasuk kedalam Bank Milik Pemerintah adalah PT. Bank Rakyat Indonesia (persero) Tbk., PT. Bank Negara Indonesia (persero) Tbk., PT. Bank Mandiri (persero) Tbk., dan PT. Bank Tabungan Negara (persero) Tbk.

Tingkat kesehatan bank dapat dinilai dari beberapa indikator.Salah satu sumber utama indikator yang dijadikan dasar penilaian adalah laporan keuangan bank yang bersangkutan. Laporan keuangan adalah laporan yang menunjukkan kondisi keuangan perusahaan pada saat ini atau dalam suatu periode tertentu (Kasmir, 2012:7). Laporan keuangan dibuat dengan maksud untuk memberikan gambaran atau laporan kemajuan yang secara periodik dilakukan pihak manajemen perusahaan yang bersangkutan. Dengan kata lain laporan keuangan bertujuan untuk menyediakan informasi yang menyangkut posisi keuangan, kinerja serta perubahan posisi keuangan suatu perusahaan yang bermanfaat bagi sejumlah besar pemakainya dalam pengambilan keputusan. Dari laporan keuangan akan terbaca bagaimana kondisi bank yang sesungguhnya, termasuk kelemahan dan kekuatan yang dimiliki. Berdasarkan laporan keuangan akan dapat dihitung sejumlah rasio yang lazim dijadikan dasar penilaian tingkat kesehatan bank. Sebelumnya sistem penilaian tingkat kesehatan bank umum menggunakan sistem penilaian yang di atur dalam Peraturan Bank Indonesia Nomor 6/10/PBI/2004 yang dikenal dengan metode CAMELS yaitu terdiri dari Capital, Asset quality, Management, Earnings, Liquidity \& Sensitivity to market risk. Sedangkan metode atau pendekatan yang digunakan dalam menilai kesehatan bank saat ini mengacu pada Peraturan Bank Indonesia No.13/1/PBI/2011 tentang Penilaian Tingkat Kesehatan Bank Umum, yaitu dengan menggunakan Pendekatan Risiko (Risk-based Bank Rating) baik secara individual maupun secara konsolidasi, dengan cakupan penilaian meliputi faktor-faktor sebagai berikut: Profil Risiko (risk profile), Good Corporate Governance (GCG), Rentabilitas (earnings); dan Permodalan (capital) atau disingkat menjadi metode RGEC. Menurut Direktur investigasi dan Advokasi Forum Independen untuk Transparansi Anggaran (Uchok Sky Khadafi : 2013), menjelaskan Bank Umum BUMN selalu mengalami kredit bermasalah, atau setiap tahun kredit bermasalah selalu meningkat. Tumbuhnya total kredit perbankan yang macet atau tidak lancar dapat dilihat dari keempat bank umum BUMN.

Tabel Kredit Bermasalah Bank Umum BUMN (dalam triliun rupiah)

\begin{tabular}{llccc}
\hline \multirow{2}{*}{ No } & \multirow{2}{*}{ Nama Perusahaan } & \multicolumn{2}{c}{ Kredit Bermasalah } & \multirow{2}{*}{ Kenaikan } \\
\cline { 3 - 4 } & & $\mathbf{2 0 1 1}$ & $\mathbf{2 0 1 2}$ & 1,3 \\
1. & Bank Rakyat Indonesia & 23,7 & 2,51 & 653,8 \\
3. & Bank Mandiri & 17,4 & 18,1 & 1,7 \\
4. & Bank Tabungan Negara & 9,2 & 11 & 1,9 \\
\hline
\end{tabular}

Kredit macet ini terjadi karena pada saat pengucuran kredit terjadi, Account Officer tidak melakukan pengecekan pengajuan kredit dengan benar sesuai tugas dan fungsi yang diemban dan dikonfirmasi atas data dokumen yang dilampirkan dalam pengajuan kredit, sehingga kredit lolos untuk disetujui. Setelah kredit dikucurkan, dalam pembayarannya kredit tersebut macet karena pihak nasabah tidak mampu lagi memenuhi kewajibannya untuk membayar fasilitas kredit yang telah diterima baik berupa kredit pokok maupun bunga. 
Tabel Data Laba, Aset, dan DPK Perusahaan Perbankan BUMN (dalam triliun rupiah)

\begin{tabular}{lllllllllll}
\hline No & $\begin{array}{l}\text { Nama } \\
\text { perusahaan }\end{array}$ & $\mathbf{3}$ & $\mathbf{2 a b a}$ & \multicolumn{3}{c}{ Aset } & \multicolumn{3}{c}{ DPK } \\
\hline 1 & Bank & $\mathbf{2 0 1 4}$ & $\mathbf{2 0 1 5}$ & $\mathbf{2 0 1 3}$ & $\mathbf{2 0 1 4}$ & $\mathbf{2 0 1 5}$ & $\mathbf{2 0 1 3}$ & $\mathbf{2 0 1 4}$ & $\mathbf{2 0 1 5}$ \\
\hline & $\begin{array}{l}\text { Mandiri } \\
\text { Bank Rakyat } \\
\text { Indonesia }\end{array}$ & 21,3 & 24,2 & 25,4 & 626,1 & 802,0 & 878,4 & 504,3 & 622,3 & 669,0 \\
3 & $\begin{array}{l}\text { Bank Negara } \\
\text { Indonesia }\end{array}$ & 9,0 & 10,8 & 9,1 & 386,6 & 416,6 & 508,6 & 291,9 & 313,9 & 370,4 \\
4 & $\begin{array}{l}\text { Bank } \\
\text { Tabungan } \\
\text { Negara }\end{array}$ & 1,6 & 1,1 & 1,8 & 131,8 & 142,1 & 168,7 & 96,2 & 106,5 & 127,7 \\
& & & & & & & & & \\
\hline
\end{tabular}

Sumber : Laporan Keuangan Masing-masing Bank

Peneliti mengambil objek penelitian pada bank umum BUMN, dengan alasan karena tertarik melihat perusahaan BUMN menjadi pelaku bisnis yang dominan di negara berkembang, termasuk di Indonesia. Terbukti dengan bank umum BUMN memiliki total aset, total modal, dan total kewajiban dalam jumlah yang besar, bahkan diantaranya memiliki total aset, total modal, dan total kewajiban terbesar di industri perbankan Indonesia. Melihat peran Bank umum BUMN yang sangat besar dalam perekonomian Indonesia dan sebagai perusahaan yang dikelola langsung oleh pemerintah, diharapkan bank umum BUMN mampu meningkatkan atau mempertahankan kinerjanya secara maksimal sehingga akan berpengaruh positif terhadap perekonomian nasional secara keseluruhan. Sebagai bank yang mendominasi perbankan di Indonesia dan menguasai hajat hidup banyak orang, maka bank dituntut untuk terus menjaga kesehatannya. Likuidasi atau bangkrutnya suatu bank yang besar dapat menyebabkan bangkrutnya bank yang lain akibat penarikan dana secara tiba-tiba. Melihat peran bank umum BUMN yang sangat strategis tersebut, maka kesehatan dan stabilitas bank umum BUMN menjadi sesuatu yang sangat vital. Oleh sebab itu peneliti merasa penting untuk melakukan analisispada bank umum BUMN untuk mengetahui kondisi kesehatan bank tersebut.

\section{LANDASAN TEORI \\ Pengertian Bank}

Menurut undang-undang no.7 tahun 1992 tentang perbankan yang telah diubah dengan Undang-undang No. 10 tahun 1998 yang dimaksudkan dengan bank adalah "Badan usaha yang menghimpun dana dari masyarakat dalam bentuk simpanan, dan menyalurkan kepada masyarakat dalam bentuk kredit dan atau bentuk-bentuk lainnya dalam rangka meningkatkan taraf hidup masyarakat banyak" (Malayu S.P Hasibuan, 2011:1). Definisi bank diatas member tekanan bahwa bank dalam melakukan usahanya terutama menghimpun dana dalam bentuk simpanan yang merupakan sumber dana bank. Demikian dari segi penyaluran dananya, hendaknya bank tidak semata-mata memperoleh keuntungan sebesar-besarnya bagi pemilik tapi juga kegiatannya itu harus pula diarahkan pada peningkatan taraf hidup masyarakat. Definisi tersebut merupakan komitmen bagi setiap bank dalam menjalankan usahanya di Indonesia. Bank merupakan lembaga keuangan yang kegiatan utamanya adalah menghimpun dana dari masyarakat dan menyalurkannya kembali dana tersebut ke masyarakat serta memberikan jasa bank lain (Kasmir, 2012 :12). Dari definisi-definisi diatas dapat disimpulkan bahwa bank merupakan lembaga yang bergerak dalam bidang keuangan, yang berperan sebagai perantara keuangan antara yang memiliki dana dan yang memerlukan dana, dan berfungsi untuk memperlancar lalu lintas pembayaran. 


\section{Laporan Keuangan}

Laporan keuangan merupakan ringkasan dari suatu proses pencatatan, merupakan suatu ringkasan dari transaksi-transaksi keuangan yang terjadi selama tahun buku yang bersangkutan. Laporan keuangan ini dibuat oleh manajemen dengan tujuan untuk mempertanggungjawabkan tugas-tugas yang dibebankan kepadanya oleh para pemilik perusahaan. Disamping itu laporan keuangan dapat juga digunakan untuk memenuhi tujuantujuan lain yaitu sebagai laporan kepada pihak-pihak diluar perusahaan (Zaki Baridwan, 2008:17). Dari definisi diatas, dapat diketahui bahwa laporan keuangan adalah laporan yang menyajikan informasi yang akan digunakan oleh pihak-pihak yang berkepentingan mengenai posisi keuangan dan kinerja perusahaan yang merupakan hasil dari proses akunatnsi selama periode akuntansi dari suatu entitas. Perusahaan baik bank maupun nonbank pada suatu waktu (periode tertentu) akan melaporkan semua kegiatan keuangannya. Menurut Kasmir (2012:280)“ laporan keuangan bank adalah laporan keuangan yang menunjukan kondisi keuangan bank secara keseluruhan. Dari laporan ini dapat diketahui bagaimana kondisi bank yang sesungguhnya, termasuk kekurangan dan keunggulan yang dimiliki.Laporan ini juga menunjukan kinerja manajemen bank selama satu periode. Keuntungan dengan membaca laporan ini pihak manajemen dapat memperbaiki kekurangan yang ada serta mempertahankan keunggulan yang dimilikinya"

\section{Kesehatan Bank}

Menurut Totok dan Sigit (2006 :22-23), Kesehatan suatu bank dapat diartikan sebagai kemampuan suatu bank untuk melakukan kegiatan operasional perbankan secara normal maupun untuk memenuhi semua kewajibannya dengan baik sesuai dengan peraturan yang berlaku. Adapun kegiatannya meliputi :

a. kemampuan untuk menghimpun dana dari masyarakat, dari lembaga lain dan modal sendiri.

b. kemampuan mengelola dana.

c. kemampuan untuk menyalurkan dana ke masyarakat.

d. kemampuan untuk memenuhi kewajiban kepada masyarakat, karyawan, pemilik modal, dan pihak lain.

e. pemenuhan peraturan perbankan yang berlaku.

Bank yang sehat adalah bank yang dapat menjaga dan memelihara kepercayaan masyarakat, dapat menjalankan fungsi intermediasi, dapat membantu kelancaran lalu lintas pembayaran serta dapat digunakan oleh pemerintah dalam melaksanakan berbagai kebijakannya, terutama kebijakan moneter.

Metode RGEC. Untuk menilai tingkat kesehatan Bank, Sesuai dengan Peraturan Bank Indonesia Nomor 13/1/PBI/2011 tentang Penilaian Tingkat kesehatan Bank Umum, Bank wajib melakukan penilaian Tingkat Kesehatan Bank dengan menggunakan pendekatan berdasarkan Risiko (Risk-based Bank Rating). Faktor faktor penilaian meliputi Profil Risiko, GCG, Rentabilitas, dan Permodalan.

1. Penilaian Profil Risiko.

Penilaian faktor profil risiko merupakan penilaian terhadap risiko inheren dan kualitas penerapan Manajemen Risiko dalam aktivitas operasional Bank. Risiko yang wajib dinilai terdiri atas delapan jenis risiko yaitu :
a. Risiko Kredit
b. Risiko Pasar
c. Risiko Likuiditas
d. Risiko Operasional
e. Risiko Hukum
f. Risiko Stratejik
g. Risiko Kepatuhan 


\section{h. Risiko Reputasi}

\section{Penilaian Good Corporate Governance (GCG)}

Berdasarkan Peraturan Bank Indonesia Nomor 8/4/PBI/2006 tanggal 30 Januari 2006 tentang Pelaksanaan Good Corporate Governance bagi Bank Umum, Pelaksanaan Good Corporate Governance pada industri perbankan harus senantiasa berlandaskan pada lima prinsip dasar, yaitu keterbukaan (transparency), akuntabilitas (accountability), pertanggungjawaban (responsibility), independensi (independency), dan kewajaran (fairness). Penilaian factor Good Corporate Governancemerupakan penilaian terhadap kualitas manajemen bank atas pelaksanaan prinsip-prinsip Good Corporate Governance. Prinsipprinsip Good Corporate Governancedan fokus penilaian terhadap pelaksanaan prinsip-prinsip Good Corporate Governance berpedoman pada ketentuan Bank Indonesia mengenai pelaksanaan Good Corporate Governance bagi Bank Umum dengan memperhatikan karakteristik dan kompleksitas usaha bank.

3. Penilaian Earning (Rentabilitas)

Penilaian faktor Rentabilitas meliputi evaluasi terhadap kinerja Rentabilitas, sumber-sumber Rentabilitas, kesinambungan Rentabilitas, dan manajemen Rentabilitas.Penilaian dilakukan dengan mempertimbangkan tingkat, trend, struktur, stabilitas rentabilitas Bank, dan perbandingan kinerja bank dengan kinerja peer group, baik melalui analisis aspek kuantitatif maupun kualitatif. Dalam menentukan peer group, Bank perlu memperhatikan skala bisnis, karakteristik, dan/atau kompleksitas usaha Bank serta ketersediaan data dan informasi yang dimiliki. Penilaian Faktor Rentabilitas dapat diukur dengan menggunakan Return On Asset (ROA). Menurut Peraturan Bank Indonesia No.14/15/PBI/2012 tentang Penilaian Kualitas Aset Bank umum, menjelaskan Aset Produktif adalah penyediaan dana Bank untuk memperoleh penghasilan, dalam bentuk kredit, surat berharga, penempatan dana antar bank, tagihan akseptasi, tagihan atas surat berharga yang dibeli dengan janji dijual kembali (reverse repurchase agreement), tagihan derivatif, penyertaan, transaksi rekening administrative, serta bentuk penyediaan dana lainnya yang dapat dipersamakan dengan itu.

4. Penilaian Capital (Permodalan)

Penilaian atas fakor permodalan meliputi evaluasi terhadap kecukupanpermodalan dan kecukupan pengelolan permodalan.Dalam melakukan perhitunganpermodalan, Bank wajib mengacu pada ketentuan Bank Indonesia yang mengaturmengenai Kewajiban Penyediaan Modal Minimum bagi Umum.Selain itu, dalammelakukan penilaian kecukupan Permodalan, Bank juga harus disediakan untukmengantisipasi risiko tersebut. Penilaian kesehatan bank adalah suatu kegiatan yang dilakukan untuk mengetahui kemampuan suatu bank untuk melakukan kegiatan operasi perbankan secara normal dan memenuhi kewajibannya. Penilaian tingkat kesehatan bank berdasarkan Peraturan Bank Indonesia penilaian kesehatan bank umum ditentukan dalam Surat Edaran No. 13/24/DPNP tanggal 25 Oktober 2011 menyatakan bahwa penilaian tingkat kesehatan bank dinilai dengan analisis RGEC yang terdiri dari : Risk (Risiko), Manajemen yang baik Good Corporate Governance (GCG), Earning (Rentabilitas) dan Capital (Permodalan). Penilaian tingkat kesehatan bank melalui RGEC ini merupakan salah satu indicator manajemen yang baik dalam mengelola perbankan dengan adanya pencapaian tingkat peringkat kesehatan bank dengan peringkat komposit 1 dan peringkat komposit.

\section{METODE PENELITIAN}

Dalam penelitian ini, penelitian deskriptif digunakan untuk menjelaskan rasio RGEC dalam menganalisis tingkat kesehatan bank umum BUMN, sedangkan kuantitatif digunakan untuk menghitung tingkat presentase rasio RGEC melalui laporan keuangan tahunan Bank Umum BUMN tahun 2012-2016. Data yang diperlukan dalam penelitian ini merupakan data 
sekunder historis, dimana diperoleh dari Laporan Keuangan Publikasi yang diterbitkan oleh bank umum BUMN periode data menggunakan data Laporan Keuangan Publikasi tahunan periode 2012 sampai dengan tahun 2016.Populasi dalam penelitian ini adalah Bank Umum BUMN yang terdaftar di Bursa Efek Indonesia tahun 2012 sampai dengan tahun 2016 yang memiliki laporan keuangan yang lengkap dan annual report yang bersangkutan. Teknik sampling merupakan teknik pengambilan sampel. Teknik pengambilan sampel yang digunakan untuk menentukan jumlah sampel dalam penelitian ini adalah nonprobability sampling. Dimana nonprobability sampling adalah teknik pengambilan sampel yang tidak memberi peluang atau kesempatan sama bagi setiap unsur atau anggota populasi untuk dipilih menjadi sampel. Pemilihan sampel dilakukan dengan menggunakan metode Sampling Jenuh, yaitu teknik penentuan sampel dengan semua anggota populasi digunakan sebagai sampel.

\section{Definisi Operasional Variabel}

Penilaian kesehatan bank merupakan penilaian terhadap kemampuan bank dalam menjalankan kegiatan operasional perbankan secara normal dan kemampuan bank dalam kewajibannya. Penilaian Tingkat Kesehatan Bank sangat penting untuk mempertahankan kepercayaan dari masyarakat dan hanya bank-bank yang benar-benar sehat saja yang dapat melayani masyarakat. Peraturan tentang penilaian kesehatan bank terdapat pada Peraturan Bank Indonesia No. 13/1/PBI/2011 dan SE No. 13/ 24/ DPNP tanggal 25 Oktober 2011 yang menjadi indicator adalah RGEC yang terdiri dari Risk atau risiko (R), Good Corporate Governance(G), Earnings(E) dan Capital(C) dan penilaiaan menggunakan skala 1 sampai 5 semakin kecil poin yang diterima itu menandakan kesehatan bank semakin baik.

\section{Instrumen Penelitian}

Secara fungsional kegunaan instrumen penelitian adalah untuk memperoleh data yang diperlukan ketika peneliti sudah menginjak pada langkah pengumpulan informasi di lapangan. Dalam instrumen penelitian data yang digunakan adalah data yang bersifat kuantitatif yang terdiri dari Metode $R G E C$ dengan menggunakan 4 rasio untuk mengukur tingkat kesehatan bank. Sedangkan data yang diperlukan dalam penelitian ini data yang diperoleh dari Laporan Keuangan Publikasi yang diterbitkan oleh bank umum BUMN periode data menggunakan Laporan Keuangan Publikasi tahunan periode 2012 sampai dengan tahun 2016.

\section{HASIL PENELITIAN DAN PEMBAHASAN}

Aspek RGEC (Risk Profile, Good Corporate Governance, Earnings, dan Capital).

Hasil penilaian tingkat kesehatan bank umum BUMN berdasarkan Metode RGEC (Risk profile, Good Corporate Governance, earnings, dan Capital) selama tahun 2012-2016 dapat disajikan dalam tabel sebagai berikut:

Penetapan Peringkat Komposit Bank umum BUMN Berdasarkan Metode RGEC

\begin{tabular}{|c|c|c|c|c|c|c|}
\hline Tahun & $\begin{array}{l}\text { Komponen } \\
\text { faktor }\end{array}$ & Rasio & Nilai & Kriteria & Ket & PK \\
\hline \multirow{5}{*}{2012} & Risk profile & $\begin{array}{l}\text { NPL } \\
\text { LDR }\end{array}$ & $\begin{array}{c}2.45 \% \\
8674 \%\end{array}$ & $\begin{array}{c}\text { Sehat } \\
\text { Cukun sehat }\end{array}$ & Sehat & \multirow{5}{*}{$\begin{array}{l}\text { Sangat } \\
\text { sehat }\end{array}$} \\
\hline & GCG & GCG & 1.36 & Sangat sehat & Sangat sehat & \\
\hline & Earnings & ROA & $3.19 \%$ & Sangat sehat & Sangat sehat & \\
\hline & & NIM & $6.13 \%$ & Sangat sehat & & \\
\hline & $\begin{array}{l}\text { Capital } \\
\text { Nilai komposit }\end{array}$ & CAR & $16.69 \%$ & Sangat sehat & Sangat sehat & \\
\hline \multirow[t]{2}{*}{2013} & Risk profile & $\begin{array}{l}\text { NPL } \\
\text { LDR }\end{array}$ & $\begin{array}{c}2.24 \% \\
92.97 \%\end{array}$ & $\begin{array}{c}\text { Sehat } \\
\text { Cukup sehat }\end{array}$ & Sehat & \multirow{2}{*}{$\begin{array}{l}\text { Sangat } \\
\text { sehat }\end{array}$} \\
\hline & GCG & GCG & 2.07 & Sehat & Sehat & \\
\hline
\end{tabular}




\begin{tabular}{|c|c|c|c|c|c|c|}
\hline & Earnings & $\begin{array}{l}\text { ROA } \\
\text { NIM }\end{array}$ & $\begin{array}{l}3.28 \% \\
6.33 \%\end{array}$ & $\begin{array}{l}\text { Sangat sehat } \\
\text { Sangat sehat }\end{array}$ & Sangat sehat & \\
\hline & $\begin{array}{l}\text { Capital } \\
\text { Nilai komposit }\end{array}$ & CAR & $15.66 \%$ & Sangat sehat & Sangat sehat & \\
\hline \multirow{4}{*}{2014} & Risk profile & $\begin{array}{l}\text { NPL } \\
\text { LDR }\end{array}$ & $\begin{array}{c}2.30 \% \\
92.51 \%\end{array}$ & $\begin{array}{c}\text { Sehat } \\
\text { Cukup sehat }\end{array}$ & Sehat & \multirow{4}{*}{$\begin{array}{l}\text { Sangat } \\
\text { sehat }\end{array}$} \\
\hline & GCG & GCG & 1.78 & Sehat & Sehat & \\
\hline & Earnings & $\begin{array}{l}\text { ROA } \\
\text { NIM }\end{array}$ & $\begin{array}{c}3.02 \% \\
6.1 \%\end{array}$ & $\begin{array}{l}\text { Sangat sehat } \\
\text { Sangat sehat }\end{array}$ & Sangat sehat & \\
\hline & $\begin{array}{l}\text { Capital } \\
\text { Nilai komposit }\end{array}$ & CAR & $16.44 \%$ & Sangat sehat & Sangat sehat & \\
\hline \multirow{5}{*}{2015} & Risk profile & $\begin{array}{l}\text { NPL } \\
\text { LDR }\end{array}$ & $\begin{array}{c}2.43 \% \\
94.82 \%\end{array}$ & $\begin{array}{c}\text { Sehat } \\
\text { Cukup sehat }\end{array}$ & Sehat & \multirow{5}{*}{$\begin{array}{c}\text { Sangat } \\
\text { sehat }\end{array}$} \\
\hline & GCG & GCG & 1.54 & Sehat & Sehat & \\
\hline & Farnings & ROA & $2.73 \%$ & Sangat sehat & Sangat sehat & \\
\hline & Calmings & NIM & $6.25 \%$ & Sangat sehat & & \\
\hline & $\begin{array}{l}\text { Capital } \\
\text { Nilai komposit }\end{array}$ & CAR & $18.91 \%$ & Sangat sehat & Sangat sehat & \\
\hline \multirow{4}{*}{2016} & Risk profile & $\begin{array}{l}\text { NPL } \\
\text { LDR }\end{array}$ & $\begin{array}{c}2.67 \% \\
93.72 \%\end{array}$ & $\begin{array}{c}\text { Sehat } \\
\text { Cukup sehat }\end{array}$ & Sehat & \multirow{4}{*}{$\begin{array}{c}\text { Sangat } \\
\text { sehat }\end{array}$} \\
\hline & GCG & GCG & 1.75 & Sehat & Sehat & \\
\hline & Earnings & $\begin{array}{l}\text { ROA } \\
\text { NIM }\end{array}$ & $\begin{array}{l}2.45 \% \\
6.31 \%\end{array}$ & $\begin{array}{l}\text { Sangat sehat } \\
\text { Sangat sehat }\end{array}$ & Sangat sehat & \\
\hline & $\begin{array}{l}\text { Capital } \\
\text { Nilai komposit }\end{array}$ & CAR & $20.99 \%$ & Sangat sehat & Sangat sehat & \\
\hline
\end{tabular}

Sumber : Data Sekunder yang diolah peneliti, 2017

Hasil analisis tingkat kesehatan bank umum BUMN berdasarkan metode RGEC selama tahun 2012-2016 menunjukkan bahwa kesehatan bank berada pada Peringkat Komposit 1(PK 1) yaitu terlihat dari keempat aspek yang diukur berupa risk profile, GCG, earnings, dan capital secara keseluruhan berada dalam peringkat sangat sehat. Selama periode tersebut dinilai sangat mampu menghadapi pengaruh negatif yang signifikan dari perubahan kondisi bisnis dan faktor eksternal lainnya tercermin dari kriteria faktor-faktor penilaian, antara lain risk profile, penerapan GCG, earnings, dan capital yang secara umum sangat baik. Apabila terdapat kelemahan maka secara umum kelemahan tersebut tidak signifikan. Ketika keadaan ekonomi Indonesia yang semakin menurun, namun hal tersebut bukanlah penghalang bagi bank umum BUMN untuk terus mempertahankan kinerja perusahaan secara keseluruhan sehingga tetap berada pada peringkat yang sangat sehat.

\section{KESIMPULAN DAN SARAN}

Berdasarkan hasil penilaian tingkat kesehatan bank umum BUMN dilihat dari aspek RGEC (Risk profile, Good Corporate Governance, Earnings, dan Capital) selama tahun 2012-2016 menempati Peringkat Komposit 1 (PK 1). Sehingga bank umum BUMN selama periode tersebut dinilai sangat mampu menghadapi pengaruh negatif secara signifikan dari perubahan kondisi bisnis dan faktor eksternal lainnya tercermin dari kriteria faktor-faktor penilaian, antara lain Risk Profile, penerapan Good Corporate Governance, Earnings, dan Capital yang secara umum sangat baik. Apabila terdapat kelemahan maka secara umum kelemahan tersebut tidak signifikan. Sebagai bank yang berstatus Bank Umum Milik Negara sebaiknya mampu mempertahankan dan terus meningkatkan tingkat kesehatan bank pada 
tahun-tahun berikutnya. Tingkat kesehatan bank yang sangat sehat akan meningkatkan kepercayaan pemegang saham, karyawan, nasabah, masyarakat, dan juga pihak lainnya terhadap bank.

\section{DAFTAR PUSTAKA}

Anggraini, Mentari; Moch. Dzulkirom AR dan Muhammad Saifi. (2015). Analisis Kinerja Keuangan Bank Konvensional Dan Bank Syariah Dengan Menggunakan Pendekatan RGEC (Studi pada PT. BRI, Tbk dan PT. BRI Syariah Periode 20112013). Jurnal Administrasi Bisnis.Vol. 27, No1.

Bank Indonesia, 2004. Peraturan Bank Indonesia No.6/10/PBI/2004 Perihal Penilaian Tingkat Kesehatan Bank Umum.

Bank Indonesia, 2007. Surat Edaran Bank Indonesia No.9/12/DPNP/2007 Perihal Pelaksanaan Good Corporate Governance Bagi Bank Umum.

Bank Indonesia, 2011. Peraturan Bank Indonesia No 13/1/PBI/2011 Tentang Penilaian Tingkat Kesehatan Bank Umum.

Bank Indonesia, 2011. Surat Edaran No.13/24/DPNP Tanggal 25 Oktober 2011 Tentang Penilaian Tingkat Kesehatan Bank Umum.

Bank Indonesia 2013, Peraturan Bank Indonesia No 15/12/PBI/2013 Tentang Kewajiban Penyediaan Modal Minimum Bank Umum.

Bank Indonesia 2012, Peraturan Bank Indonesia No.14/15/PBI/2012 Tentang Penilaian Kualitas Aset Bank Umum.

Baridwan, Zaki, 2004. Intermediate Accounting, Edisi Revisi. Yogyakarta : BPFEYogyakarta.

Bursa Efek Indonesia. Laporan Keuangan dan Tahunan.

Darussalam, Olyvia.(2013). Faktor-faktor Penyebab Kredit Bermasalah Di PT. Bank Sulut Cabang Utama Manado. Jurnal EMBA Vol 1,No 4, Desember.

Dianti, Edla.(2016). Analisis Tingkat Kesehatan Bank Dengan Menggunakan Metode RGEC (Studi pada Bank Swasta yang Terdaftar di Bursa Efek Indonesia). Jurnal JOM Fisip Vol 3, No 2, Oktober.

Hasibuan, Malayu S.P. 2011. Dasar-dasar Perbankan. Jakarta : PT.Bumi Aksara.

Hessel Nogi S. (2003). Good Corporate Governance. Balairung \&Co :Yogyakarta.

Kasmir, 2015. Analisis Laporan Keuangan. Jakarta : PT. Raja Grafindo Persada.

Kasmir, 2012. Manajemen Perbankan, Edisi Revisi. Jakarta: Rajawali Pers.

Mais, Rimi Gusliana, Dita Indah Sari. (2015). EvaluationOf Banks Health Rate Of Indonesia And Malaysia Islamic Bank With RGEC Method. Indonesia College Of Economis (STEI).

Mudrajat Kuncoro dan Suhardjono. 2011. Manajemen Perbankan Teori dan Aplikasi. Yogyakrta: BPFE.

Muniroh, Dwi Sahrul. (2014). Analisis Kinerja Keuangan Menggunakan Metode RGEC (Risk, GCG, Earnings, Capital) Pada Sektor Keuangan Perbankan. Jurnal Ilmu Manajemen. Vol. 2.No.2.

Rahman, Tessa Aulia., Nengah Sudjana, dan Zahroh ZA. 2016. Analisis Kinerja Perbankan dengan Pendekatan RGEC (Risk Profile, Good Corporate Governance, Earning, and Capital) untuk Mengetahui Tingkat Kesehatan Bank (Studi pada Bank BUMN dan Bank Pembangunan Daerah Periode 2012-2014).Jurnal Administrasi Bisnis (JAB). Vol. 35, No.1.

Ramadhany, Adinda Putri, Suhadak, dan Zahroh Z.A. (2015). Analisis

Perbandingan Tingkat Kesehatan Bank Berdasarkan Risk Profie, Good Corporate Governance, Earnings Dan Capital RGEC) Pada Bank Konvensional BUMN Dan 
Swasta (Studi pada Bank Umum Milik Negara dan Bank Swasta Nasional Devisa yang Terdaftar di Bursa Efek Indonesia Periode 2011-2013). Jurnal Administrasi Bisnis (JAB). Vol. 23, No.1.

Septa Riadi, Kadek; Anantawikrama Tungga Atmadja, dan Made ArieWahyuni.

(2016). Penilaian Tingkat KEesehatan Bank Dengan Menggunakan Metode RGEC (Risk Profile, Good Corporate Governance, Earnings, Dan Capital) Pada PT. Bank Mandiri (Persero), Tbk Periode 2013-2015.Vol. 6, No.3.

Setiawan, Dini Novyanti.(2014). Pengaruh Rasio CAMEL terhadap Tingkat Kesehatan Di Bank Tabungan Negara Syariah. Skripsi. STIE Kesatuan Bogor.

Sugiyono. (2014). Metode Penelitian Kuantitatif, Kualitatif, dan R\&D.

Sigit Tri Andaru, A. Totok budi Santoso.(2006). Bank dan Lembaga Keuangan Lainnya, Salemba Empat, Jakarta.

Undang-undang, 1992. Undang-undang No.7 tahun 1992, Tentang Perbankkan.

Undang-undang. 1998. Undang-undang No. 10 Tahun 1998, Tentang Perbankan. 